\title{
Differences in Selected Health Traits between Occupational Groups among Oraons of Jalpaiguri District, West Bengal
}

\author{
Subrata K. Roy and Tanaya Kundu Chowdhury \\ Biological Anthropology Unit, Indian Statistical Institute, 203 B.T. Road, Kolkata 700 108, India \\ Correspondence should be addressed to Subrata K. Roy; rsubrata@isical.ac.in
}

Received 30 September 2013; Revised 15 November 2013; Accepted 29 November 2013

Academic Editor: Kaushik Bose

Copyright ( $) 2013$ S. K. Roy and T. Kundu Chowdhury. This is an open access article distributed under the Creative Commons Attribution License, which permits unrestricted use, distribution, and reproduction in any medium, provided the original work is properly cited.

\begin{abstract}
Occupational health deals with diseases or injuries caused due to work. Different types of work cause different types of illeffect on health and may cause changes in health traits; empirical studies on the issues are scanty. The present study aims to investigate the differences in selected health traits between two occupational groups of the same ethnic origin. Cross-sectional data collected on 357 adult Oraon labourers engaged in two different occupations, namely, agriculture and brickfield in Jalpaiguri district, West Bengal, of which are 62 male and 43 female agricultural labourers and 136 male and 116 female brickfield labourers. Data consists of anthropometric measurements, blood pressure, and haemoglobin traits. Health status assessed in terms of BMI, systolic and diastolic blood pressure, and haemoglobin level following standard cut-off values. Mean values of both the occupational groups show similar trends in case of selected anthropometric and health traits. Individuals are ecto-mesomorphic irrespective of sex and occupation. Majority of individuals of either sex of both the occupational groups are underweight but hypertensive. In anthropological data, the trend of mean values is important than mere statistical significance. Data indicates that both the occupational groups have similar health condition, maybe due to their heavy manual activity.
\end{abstract}

\section{Introduction}

Occupation that generates income [1] plays a vital role in the well-being of individuals [2] engaged in jobs. But many working conditions create physical and mental stress that causes ill effects on health and enhance the chances of several infectious [3], communicable [4], and noncommunicable diseases $[5,6]$. In view of the problems in different occupations and working environments, World Health Organization had taken a Global Strategy on Occupational Health for All by the Year 2000 [7]. India has also included occupational and environmental health as area of concern in the tenth five-year plan (2002-2007) [8].

In recent times, emphasis is given primarily on sedentary occupations which may enhance the chances of cardiovascular diseases [9], diabetes [10], and cancer [11]. Night shifting work can disturb biological clock and may have some ill effects on health [12] and increases the chances of cardiovascular diseases [13] and diabetes [14]. Heavy manual labour too can cause low back pain $[15,16]$, injuries [17], musculoskeletal problems [18], and so forth, to the workers. Workers at mining and quarry industries suffer from lung problems $[19,20]$ and hearing loss $[21]$ due to their working environment. Agriculture is the main occupation in rural India. The people who work at agricultural field and plantation area may suffer from worm infestation [22] and snake bite [23] as they have to work in bare foot. Pesticide poisoning is another risk for agricultural worker [24]. Sugar cane farmers suffer from several lung diseases [6]. Not only physical health, but also the mental health is affected due to job stress [25]. Fear of losing job and unemployment may also prevent one from taking health care timely [26].

Apart from diseases and injuries, sedentary occupations may increase chances of obesity [27] due to low level of physical activity; on the other hand, high physical activity demanding occupations may lead to underweight [28]. 
Working overtime may leads to increase in BMI and waist circumferences in white-collar male workers [29]. Manual workers develop better hand grip strength than sedentary individuals [30] but suffer from anaemia [22]. Work in brick field demands heavy manual labour (for carrying heavy loads for a long hour), which may enable labourers to achieve greater physical strength, due to extensive use of their muscles [31] or vice versa. It is reported that among the brick field worker aerobic capacity varies across different types of work [32].

In view of the above, it can intuitively be understandable that different types of work may cause different types of ill health effect. The changes can be reflected from the health traits of the individuals engaged in different occupations. However, studies on this issue are limited in the Indian context [30]. Thus, the present study aims to investigate the differences in selected health traits between two occupational groups of the same ethnic origin.

\section{Material and Methods}

2.1. Population and Area. Present cross-sectional data was collected from Oraon labourers engaged in two different occupations, namely, agriculture and brickfield, living adjacent to Birpara Police Station of the Jalpaiguri district of West Bengal. The present study was part of a larger biocultural research project. The study was restricted to single ethnic (endogamous) group, Oraon, in order to eliminate possible ethnic/genetic effect in different health-related traits. The Oraon is a Dravidian speaking tribal population who inhabited mainly Chotanagpur regions and Santhal Parganas of Bihar [33]. They have been supposed to have migrated about 100 years ago to Jalpaiguri area from their original homeland mainly as tea garden labourers [33] and at present they work as labourers at agricultural field and brickfield also.

2.2. Data Collection and Data Types. Data were collected from the individuals of both sexes, who volunteered to participate in the study. No statistical sampling of the individuals had been done because of some obvious difficulties in the field like suspicion. Complete enumeration was done for sociodemographic data from all the Oraon households of Rangalibajna village of Madarihat Police Station for agricultural labourers and Etelbari village of Birpara Police Station for brickfield labourers following well-tested questionnaire/schedule. After that, data on anthropometric and blood parameters were taken from the adult individuals of both sexes who volunteer to participate in the study. A total of 357 adult individuals had been measured including 62 male and 43 female agricultural labourers and 136 male and 116 female brickfield labourers. Both groups live in very close proximity; therefore, the possible effect of physical environment on health related traits can be ruled out.

Anthropometric data were taken by a single investigator (Subrata K. Roy) following IBP (International Biological Programme) basic list of measurements, using standard techniques and instruments [34], including: stature $(\mathrm{cm})$, weight (kg), mid-upper arm circumference $(\mathrm{cm})$, calf circumference $(\mathrm{cm})$, chest circumferences in inhalation and exhalation $(\mathrm{cm})$, anteroposterior and transverse chest diameters $(\mathrm{cm})$, Biepicondylar breadth of humerous $(\mathrm{cm})$, Bicondylar breadth of femur $(\mathrm{cm})$, biceps skinfold thickness, $(\mathrm{mm})$, triceps skinfold thickness (mm), subscapular skinfold thickness, $(\mathrm{mm})$, suprailiac skinfold thickness $(\mathrm{mm})$, and calf skinfold thickness (mm).

Blood pressure data was measured using mercury sphygmomanometer and stethoscope following AHA standards; data includes systolic (SBP) and diastolic (DBP) blood pressure. Pulse rate was also measured for 30 seconds feeling the radial artery on left hand. Haemoglobin level was measured using oxyhaemoglobin method following standard techniques [35]. Body mass index (BMI) has been calculated from the anthropometric measurements using the formula: BMI = body weight $(\mathrm{kg}) /$ stature $\left(\mathrm{m}^{2}\right)$.

2.3. Somatotype Rating. The anthropometric somatotype techniques have been used following Carter and Heath [36].

Endomorphy was determined by using the following formula: $0.0000014\left(X^{3}\right)-0.00068\left(X^{2}\right)+0.1451(X)-0.7182$, where $X$ is the sum of triceps, subscapular, and suprailiac skinfold thickness adjusted for stature; that is, $X=$ sum of the skinfold thickness $\times(170.18 /$ stature $)$.

Mesomorphy has been determined by using the following formula: $[(0.858 \times$ biepicondylar diameter of humerous $)+$ $(0.601 \times$ bicondylar diameter of femur $)+\{0.188 \times($ midupper arm circumference - triceps skinfold $)\}+\{0.161 \times($ calf circumference - calf skinfold $)\}]-($ stature $\times 0.131)+4.50$. As a note of caution both triceps and calf skinfold thickness have been measured in millimeter scale and at the time of subtraction this unit has been converted into centimetre scale in order to equalize the unit of measurement.

Ectomorphy has been obtained by using the formula $\mathrm{HWR}$ (height weight ratio) $\times 0.732-28.58$, where $\mathrm{HWR}=$ Stature/Weight ${ }^{1 / 3}$. If HWR is less than 40.75 but greater than 38.25 , ectomorphy has been determined by using HWR $\times$ $0.463-17.63$. If HWR is equal to or less than 38.25 , a rating of 0.1 has been assigned to the ectomorphy rating.

The $X$ and $Y$ coordinate have been calculated using the following formulae:

$$
\begin{aligned}
& X=\text { ectomorphy }- \text { endomorphy, } \\
& Y=2 \times \text { mesomorphy }- \text { (ectomorphy }+ \text { endomorphy })
\end{aligned}
$$

2.4. Classification of Data. BMI values were classified as severe thinness $\left(<16.00 \mathrm{~kg} / \mathrm{m}^{2}\right)$, moderate thinness $(16.00-$ $\left.16.99 \mathrm{~kg} / \mathrm{m}^{2}\right)$, mild thinness $\left(17.00-18.49 \mathrm{~kg} / \mathrm{m}^{2}\right)$, normal $\left(18.50-24.99 \mathrm{~kg} / \mathrm{m}^{2}\right)$, overweight $\left(25.00-29.99 \mathrm{~kg} / \mathrm{m}^{2}\right)$ and Obese $\left(\geq 30.00 \mathrm{~kg} / \mathrm{m}^{2}\right)$ following standard cut-off values [37]. Haemoglobin level was classified as normal (male $>13 \mathrm{~g} / \mathrm{dL}$, female $>12 \mathrm{~g} / \mathrm{dL}$ ), mild anaemic (male 11.0-12.9 g/dL, female $11.0-11.9 \mathrm{~g} / \mathrm{dL})$, moderate anaemic $(8.0-10.9 \mathrm{~g} / \mathrm{dL})$, and severe anaemic $(<8.0 \mathrm{~g} / \mathrm{dL})$ according to WHO classification [38]. Blood pressure data were classified as normal $(\mathrm{SBP}<120$ and DBP > $80 \mathrm{~mm} \mathrm{Hg}$ ), prehypertensive (SBP 120-139 or DBP $80-89 \mathrm{~mm} \mathrm{Hg}$ ), stage 1 hypertensive (SBP $140-159$ or DBP 90-99 $\mathrm{mm} \mathrm{Hg}$ ), and stage II hypertensive (SBP $\geq 160$ or 
TABLE 1: Descriptive statistics of selected anthropometric traits of agricultural and brickfield labourers of either sex.

\begin{tabular}{|c|c|c|c|c|c|c|c|c|c|c|}
\hline \multirow{3}{*}{$\begin{array}{l}\text { Selected anthropometric } \\
\text { traits }\end{array}$} & \multicolumn{5}{|c|}{ Male } & \multicolumn{5}{|c|}{ Female } \\
\hline & \multicolumn{2}{|c|}{$\begin{array}{c}\text { Agricultural } \\
\text { labourer }(n=62)\end{array}$} & \multicolumn{2}{|c|}{$\begin{array}{l}\text { Brickfield labourer } \\
\qquad(n=136)\end{array}$} & \multirow[t]{2}{*}{$\begin{array}{c}t \text {-test } \\
(\mathrm{df}=196)\end{array}$} & \multicolumn{2}{|c|}{$\begin{array}{c}\text { Agricultural } \\
\text { labourer }(n=43)\end{array}$} & \multicolumn{2}{|c|}{$\begin{array}{l}\text { Brickfield labourer } \\
\qquad(n=116)\end{array}$} & \multirow[t]{2}{*}{$\begin{array}{c}t \text {-test } \\
(\mathrm{df}=157)\end{array}$} \\
\hline & Mean & S.D & Mean & S.D & & Mean & S.D & Mean & S.D & \\
\hline Age (years) & 31.00 & 10.88 & 34.79 & 11.64 & $2.17^{*}$ & 29.14 & 7.84 & 30.62 & 10.16 & 0.87 \\
\hline Stature $(\mathrm{cm})$ & 163.56 & 6.33 & 161.57 & 6.52 & $2.01^{*}$ & 151.53 & 5.81 & 149.50 & 5.81 & 1.95 \\
\hline Weight (kg) & 48.71 & 4.77 & 47.94 & 5.98 & 0.89 & 41.24 & 4.44 & 40.83 & 4.65 & 0.51 \\
\hline BMI $\left(\mathrm{kg} / \mathrm{m}^{2}\right)$ & 18.21 & 1.45 & 18.34 & 1.77 & 0.52 & 17.93 & 1.35 & 18.27 & 1.89 & 1.08 \\
\hline \multicolumn{11}{|l|}{ Circumferences $(\mathrm{cm})$} \\
\hline Midupper arm & 22.45 & 1.33 & 22.17 & 1.79 & 1.10 & 20.69 & 1.30 & 20.83 & 1.92 & 0.42 \\
\hline Calf & 29.02 & 1.72 & 28.11 & 3.01 & $2.21^{*}$ & 27.15 & 1.58 & 26.79 & 2.72 & 0.79 \\
\hline Chest (exhalation) & 79.66 & 3.57 & 77.76 & 4.09 & $3.14^{*}$ & 71.64 & 6.27 & 72.72 & 4.18 & 1.26 \\
\hline Chest (Inhalation) & 82.02 & 3.65 & 79.99 & 4.05 & $3.36^{* *}$ & 74.25 & 3.93 & 74.21 & 3.78 & 0.06 \\
\hline \multicolumn{11}{|l|}{ Chest diameters $(\mathrm{cm})$} \\
\hline Anteroposterior & 23.93 & 1.43 & 24.85 & 4.68 & 1.52 & 22.05 & 1.18 & 22.85 & 1.67 & $2.86^{*}$ \\
\hline Transverse & 17.49 & 1.41 & 17.24 & 1.29 & 1.19 & 15.96 & 1.33 & 15.64 & 1.12 & 1.54 \\
\hline \multicolumn{11}{|l|}{ Skinfold thicknesses (mm) } \\
\hline Biceps & 3.19 & 0.56 & 2.81 & 0.88 & $3.22^{* *}$ & 4.05 & 1.13 & 4.02 & 1.87 & 0.13 \\
\hline Triceps & 5.15 & 1.23 & 4.62 & 1.63 & $2.26^{*}$ & 8.34 & 1.23 & 8.30 & 1.63 & 0.07 \\
\hline Calf & 4.74 & 1.18 & 4.69 & 1.90 & 0.19 & 7.4 & 2.08 & 7.61 & 3.04 & 0.41 \\
\hline Subscapular & 8.69 & 1.44 & 7.81 & 3.05 & $2.14^{*}$ & 9.53 & 2.51 & 9.52 & 3.26 & 0.01 \\
\hline Suprailiac & 5.69 & 1.43 & 5.2 & 2.51 & 1.44 & 6.99 & 3.02 & 6.59 & 3.73 & 0.64 \\
\hline
\end{tabular}

${ }^{*} P<0.05,{ }^{* *} P<0.01$.

TABle 2: Descriptive statistics of somatotype components in agricultural and brickfield labourers of either sex.

\begin{tabular}{|c|c|c|c|c|c|c|c|c|c|c|}
\hline \multirow{3}{*}{ Somatotype components } & \multicolumn{5}{|c|}{ Male } & \multicolumn{5}{|c|}{ Female } \\
\hline & \multicolumn{2}{|c|}{$\begin{array}{c}\text { Agriculture } \\
\text { labourer }(n=62)\end{array}$} & \multicolumn{2}{|c|}{$\begin{array}{l}\text { Brickfield labourer } \\
\quad(n=136)\end{array}$} & \multirow{2}{*}{$\begin{array}{c}t \text {-test } \\
(\mathrm{df}=196)\end{array}$} & \multicolumn{2}{|c|}{$\begin{array}{c}\text { Agriculture } \\
\text { labourer }(n=43)\end{array}$} & \multicolumn{2}{|c|}{$\begin{array}{l}\text { Brickfield labourer } \\
\quad(n=116)\end{array}$} & \multirow{2}{*}{$\begin{array}{c}t \text {-test } \\
(\mathrm{df}=157)\end{array}$} \\
\hline & Mean & S.D. & Mean & S.D. & & Mean & S.D. & Mean & S.D. & \\
\hline Endomorphy & 1.81 & 0.44 & 1.77 & 0.68 & 0.36 & 2.45 & 0.76 & 2.77 & 1.09 & 1.71 \\
\hline Mesomorphy & 2.72 & 0.84 & 2.70 & 0.90 & 0.46 & 2.22 & 0.74 & 2.46 & 0.96 & 1.00 \\
\hline Ectomorphy & 4.24 & 1.02 & 4.12 & 1.05 & 0.75 & 3.59 & 0.88 & 3.36 & 1.15 & 1.21 \\
\hline$X$ & 2.44 & 1.15 & 2.35 & 1.45 & 0.40 & 1.14 & 1.49 & 0.59 & 1.97 & 1.65 \\
\hline$Y$ & -0.57 & 2.61 & -0.54 & 2.49 & 0.07 & -1.53 & 1.89 & -1.28 & 2.46 & 0.59 \\
\hline
\end{tabular}

TABLE 3: Descriptive statistics of selected health traits in brickfield and agricultural labourers of either sex.

\begin{tabular}{|c|c|c|c|c|c|c|c|c|c|c|}
\hline \multirow{3}{*}{ Selected health traits } & \multicolumn{5}{|c|}{ Male } & \multicolumn{5}{|c|}{ Female } \\
\hline & \multicolumn{2}{|c|}{$\begin{array}{c}\text { Agricultural } \\
\text { labourer }(n=62)\end{array}$} & \multicolumn{2}{|c|}{$\begin{array}{l}\text { Brickfield labourer } \\
\qquad(n=136)\end{array}$} & \multirow{2}{*}{$\begin{array}{c}t \text {-test } \\
(\mathrm{df}=196)\end{array}$} & \multicolumn{2}{|c|}{$\begin{array}{c}\text { Agricultural } \\
\text { labourer }(n=43)\end{array}$} & \multicolumn{2}{|c|}{$\begin{array}{l}\text { Brickfield labourer } \\
\qquad(n=116)\end{array}$} & \multirow{2}{*}{$\begin{array}{c}t \text {-test } \\
(\mathrm{df}=157)\end{array}$} \\
\hline & Mean & S.D & Mean & S.D & & Mean & S.D & Mean & S.D & \\
\hline $\begin{array}{l}\text { Systolic blood pressure } \\
(\mathrm{mm} . / \mathrm{Hg})\end{array}$ & 127.15 & 16.67 & 126.05 & 22.22 & 0.35 & 124.51 & 16.93 & 120.09 & 25.75 & 1.04 \\
\hline $\begin{array}{l}\text { Diastolic blood pressure } \\
(\mathrm{mm} . / \mathrm{Hg})\end{array}$ & 84.35 & 10.05 & 82.34 & 13.29 & 1.06 & 84.28 & 13.76 & 81.39 & 15.45 & 1.08 \\
\hline Pulse rate (bits/min) & 73.61 & 9.42 & 75.48 & 9.19 & 1.31 & 76.33 & 9.74 & 78.62 & 11.89 & 1.14 \\
\hline Hemoglobin level (g/dL) & 11.87 & 1.58 & 10.84 & 2.62 & $2.86^{*}$ & 9.29 & 1.62 & 8.61 & 2.15 & 1.88 \\
\hline
\end{tabular}

${ }^{*} P<0.05$. 
TABLE 4: Classification of age and selected health traits in brickfield and agricultural labourers of male and female, respectively.

\begin{tabular}{|c|c|c|c|c|c|c|c|c|}
\hline & \multicolumn{4}{|c|}{ Male } & \multicolumn{4}{|c|}{ Female } \\
\hline & \multicolumn{2}{|c|}{$\begin{array}{c}\text { Agricultural } \\
\text { labourer }(n=62)\end{array}$} & \multicolumn{2}{|c|}{$\begin{array}{l}\text { Brickfield labourer } \\
\qquad(n=136)\end{array}$} & \multicolumn{2}{|c|}{$\begin{array}{c}\text { Agricultural } \\
\text { labourer }(n=43)\end{array}$} & \multicolumn{2}{|c|}{$\begin{array}{c}\text { Brickfield labourer } \\
\quad(n=116)\end{array}$} \\
\hline & $n$ & $\%$ & $n$ & $\%$ & $n$ & $\%$ & $n$ & $\%$ \\
\hline \multicolumn{9}{|l|}{ Age groups (years) } \\
\hline Up to 20 & 8 & 12.90 & 14 & 10.29 & 4 & 9.30 & 20 & 17.24 \\
\hline $21-30$ & 30 & 48.39 & 50 & 36.76 & 24 & 55.81 & 45 & 38.79 \\
\hline $31-40$ & 13 & 20.97 & 30 & 22.06 & 10 & 23.26 & 31 & 26.72 \\
\hline $41-50$ & 8 & 12.90 & 27 & 19.85 & 5 & 11.63 & 17 & 14.66 \\
\hline More than 50 & 3 & 4.84 & 15 & 11.03 & - & - & 3 & 2.59 \\
\hline \multicolumn{9}{|c|}{ BMI category (WHO, 2004) } \\
\hline Severe thinness & 3 & 4.83 & 8 & 5.88 & 2 & 4.65 & 10 & 8.62 \\
\hline Moderate thinness & 10 & 16.12 & 17 & 12.50 & 8 & 18.60 & 18 & 15.51 \\
\hline Mild thinness & 26 & 41.93 & 50 & 36.76 & 20 & 46.51 & 38 & 32.75 \\
\hline Normal & 23 & 37.09 & 58 & 42.64 & 13 & 30.23 & 50 & 43.10 \\
\hline Overweight & - & - & 2 & 1.47 & - & - & - & - \\
\hline \multicolumn{9}{|c|}{ Anaemic status (WHO, 2011) } \\
\hline Severe & 1 & 1.61 & 9 & 6.72 & 10 & 23.26 & 36 & 31.03 \\
\hline Moderate & 6 & 9.68 & 47 & 35.07 & 26 & 60.47 & 66 & 56.90 \\
\hline Mild & 40 & 64.52 & 53 & 39.55 & 7 & 16.28 & 11 & 9.48 \\
\hline Normal & 15 & 24.19 & 25 & 18.66 & - & - & 3 & 2.59 \\
\hline \multicolumn{9}{|c|}{ Blood pressure category (JNC 7) } \\
\hline Normal & 12 & 19.35 & 47 & 35.07 & 13 & 30.23 & 51 & 43.97 \\
\hline Prehypertensive & 31 & 50.00 & 46 & 34.33 & 16 & 37.21 & 37 & 31.90 \\
\hline Stage 1 hypertension & 11 & 17.74 & 23 & 17.16 & 9 & 20.93 & 9 & 7.76 \\
\hline Stage 2 hypertension & 8 & 12.90 & 18 & 13.43 & 5 & 11.63 & 19 & 16.38 \\
\hline
\end{tabular}

$\mathrm{DBP} \geq 100 \mathrm{~mm} \mathrm{Hg}$ ) according to $\mathrm{JNC}-7$ blood pressure classification [39].

2.5. Analysis of Data. Descriptive statistics and $t$-statistic have been used to find out the differences in selected health traits, that is, anthropometric, blood pressure, pulse rate and haemoglobin traits between the two occupational groups. The collected data were analysed using SPSS version 16.0 (SPSS Inc., Chicago, IL, USA).

\section{Results}

Table 1 shows the descriptive statistics of selected anthropometric traits of the two occupational groups, separately for sexes. Male agricultural labourers show higher mean values in almost all the anthropometric traits than male brickfield labourers, but the differences are significant only in case of stature, calf and chest circumferences, biceps, triceps, and subscapular skinfolds. In females, agricultural labourers show higher mean values in most of the traits than brick field labourers but the differences are not significant except for antero-posterior chest diameter.

Table 2 shows the descriptive statistics of somatotype components of male and female labourers working in agriculture and brickfield. All the individuals, irrespective of sex and occupation, show higher ectomorphic component than endomorphic component. No statistically significant differences were observed in any of the comparisons. All the individuals irrespective of sex and occupation belong to mesoectomorphic region.

Table 3 shows the descriptive statistics of systolic and diastolic blood pressure, pulse rate, and haemoglobin level of agricultural and brick field labourers separately for sexes. Male agricultural labourers, show higher mean values of all the traits compared to brickfield labourers but a significant difference lies only in case of haemoglobin level. A similar trend is observed in case of females as that of males but the differences were not statistically significant. Moreover, the haemoglobin level in all the individuals was below the normal category [38].

Table 4 shows the classification of age and selected health traits, namely, BMI, haemoglobin, and blood pressure of the studied individuals. Majority of individuals belong to age group 21-30. Result shows that majority of individual are underweight (BMI), especially mild thin, irrespective of sex and occupational status. Majority of the males of both the occupational groups were categorized under "mild anaemic," whereas majority of females of both occupational groups were categorized under "moderate anaemic" in terms of haemoglobin level. Blood pressure category reveals that 
majority of agricultural labourers of either sex are prehypertensive, whereas majority of brickfield labourers of either sex have normal blood pressure.

\section{Discussion}

The present study aims to investigate the differences in selected health traits between two occupational groups, namely, agriculture and brickfield. The individuals of both groups were homogenous in terms of ethnic/genetic traits, physical environment, and socioeconomic condition. Health status was measured in terms of few anthropometric traits, blood pressure, pulse rate, and haemoglobin level. The test protocols were similar for all the individuals under study. Results show an overall poor health condition of the labourers in both occupational groups.

Mean values of anthropometric traits show relatively greater values among agricultural labourers in almost all the traits than among brickfield labourers. The values are relatively poorer than those observed in other indigenous populations of India, as well as of West Bengal [40, 41]. Somatotype components of either sex show no statistically significant difference of the occupational groups. But the value of ectomorphic component is higher in all the individuals, an inevitable characteristic of manual labourer [42, 43]. The values of $X$ and $Y$ indicate that all the individuals can be plotted in the ecto-meso region of somatotype chart (not presented). This finding is corroborative with the study of Roy [44], where ectomorphic component was predominant in both high and low tea leaf pluckers irrespective of sex.

BMI values show that majority of individuals are underweight and especially mild thinness is prevalent irrespective of sex and occupational status. This finding corroborates with the study of Mittal and Srivastava [45], where prevalence of undernutrition, especially mild thinness was higher for both Oraon male, and females. Among Oraon males of Jharkhand, engaged in both agriculture and wage earner jobs, higher prevalence of undernutrition [46] and mild thinness was also reported [47]. Bigoniya and colleagues [28] also reported majority of gardeners of Bhopal city were underweight. Prevalence of underweight is high among the tea garden labourers of Assam [22, 48]. London et al. [49] also reported high level of undernutrition (low BMI values) among the farm workers of Western Cape. Therefore, the present study shows the same trend as of earlier studies in case of BMI values.

Considering haemoglobin level of the occupational groups, majority of males show mild anaemic status, whereas majority of females of both occupational groups were moderate anaemic. Female agricultural labourers failed to show normal haemoglobin level. This finding is corroborative with the findings of Medhi et al. [22] for Assam tea garden labourers.

Mean values of systolic and diastolic blood pressure and pulse rate of either sex are higher in case of agricultural labourers than in case of brickfield labourers. Blood pressure category reveals that, majority of brickfield labourers of either sex have normal blood pressure but majority of agricultural labourer of either sex were pre-hypertensive. The high prevalence of prehypertensive individuals was also reported in the studies of Medhi et al. [22] and Mahanta and colleagues [50] among the tea garden labourers of Assam.

However, health status of the two occupational groups under study shows more or less similar values in terms of the variables considered, which may perhaps be related to the high demand of physical activity in such jobs (occupations). Such result is expected in many high physical activity demanding jobs; the truth is verified with the statement of House et al. [51] and Karasek et al. [52] which states that each particular occupation has its own set of demands and rewards that can influence health.

\section{Conclusion}

The result obtained in the study is not sufficient to make some general remarks, because the differences in health traits were not significant in all the traits between groups and even the trends of mean values were not consistently high in any particular group. But many studies revealed the existence of such differences. Therefore, more studies across communities and occupations with rigorous study design and proper sample size should be necessary to get more meaningful insights into the facts.

\section{Authors' Contribution}

Both the authors participated in study design, data analysis and writing of the paper. Subrata K. Roy collected the field data for the present study.

\section{Conflict of Interest}

No author had any financial or personal conflict of interests with the organization supporting the research.

\section{Acknowledgments}

The authors are indebted to the people of the study areas for their unhesitating help and cooperation. Financial and logistic support had been given by the Indian Statistical Institute to conduct this work. Both the authors participated in study design, data analysis and writing the manuscript. Subrata K. Roy collected the field data for the present study.

\section{References}

[1] J. De Beyer and J. B. Knight, "The role of occupation in the determination of wages," Oxford Economic Papers, vol. 41, no. 1, pp. 595-618, 1989.

[2] M. Law, S. Steinwender, and L. Leclair, "Occupation, health and well-being," Canadian Journal of Occupational Therapy, vol. 65, no. 2, pp. 81-91, 1998.

[3] J. A. Haagsma, L. Tariq, D. J. Heederik, and A. H. Havelaar, "Infectious disease risks associated with occupational exposure: a systematic review of the literature," Occupational and Environmental Medicine, vol. 69, no. 2, pp. 140-146, 2012. 
[4] M. Oldenburg, X. Baur, and C. Schlaich, "Occupational risks and challenges of seafaring," Journal of Occupational Health, vol. 52, no. 5, pp. 249-256, 2010.

[5] B. Sjögren, J. Weiner, and K. Larsson, "Ischaemic heart disease among livestock and agricultural workers," Occupational and Environmental Medicine, vol. 60, no. 8, p. el, 2003.

[6] D. K. Amre, C. Infante-Rivard, A. Dufresne, P. M. Durgawale, and P. Ernst, "Case-control study of lung cancer among sugar cane farmers in India," Occupational and Environmental Medicine, vol. 56, no. 8, pp. 548-552, 1999.

[7] WHO Collaborating Centres in Occupational Health, Global Strategy on Occupational Health for All: The Way to Health at Work, World Health Organization, Geneva, Switzerland, 1994.

[8] H. N. Saiyed and R. R. Tiwari, "Occupational health research in India," Industrial Health, vol. 42, no. 2, pp. 141-148, 2004.

[9] M. A. Pereira, A. M. Kriska, V. R. Collins et al., "Occupational status and cardiovascular disease risk factors in the rapidly developing, high-risk population of Mauritius," American Journal of Epidemiology, vol. 148, no. 2, pp. 148-163, 1998.

[10] Y. Morikawa, H. Nakagawa, M. Ishizaki et al., "Ten-year followup study on the relation between the development of non-insulin-dependent diabetes mellitus and occupation," American Journal of Industrial Medicine, vol. 31, no. 1, pp. 80-84, 1997.

[11] E. Pukkala, J. I. Martinsen, E. Lynge et al., "Occupation and cancer follow-up of 15 million people in five Nordic countries," Acta Oncologica, vol. 48, no. 5, pp. 646-790, 2009.

[12] J. Natti, T. Anttila, T. Oinas, and A. Mustosmki, "Night work and mortality: prospective study among Finnish employees over time span 1984 to 2008," Chronobiology International, vol. 29, no. 5, pp. 601-609, 2012.

[13] L. Tenkanen, T. Sjöblom, R. Kalimo, T. Alikoski, and M. Härmä, "Shift work, occupation and coronary heart disease over 6 years of follow-up in the Helsinki Heart Study," Scandinavian Journal of Work, Environment and Health, vol. 23, no. 4, pp. 257-265, 1997.

[14] A. Pan, E. S. Schernhammer, Q. Sun, and F. B. Hu, "Rotating night shift work and risk of type 2 diabetes: two prospective cohort studies in women," PLoS Medicine, vol. 8, no. 12, Article ID e1001141, pp. 1-8, 2011.

[15] A. Mazloum, H. Nozad, and M. Kumashiro, "Occupational low back pain among workers in some small-sized factories in Ardabil, Iran," Industrial Health, vol. 44, no. 1, pp. 135-139, 2006.

[16] W. Eriksen, B. Natvig, and D. Bruusgaard, "Smoking, heavy physical work and low back pain: a four-year prospective study," Occupational Medicine, vol. 49, no. 3, pp. 155-160, 1999.

[17] S. M. Barreto, A. J. Swerdlow, P. G. Smith, and C. D. Higgins, "A nested case-control study of fatal work related injuries among Brazilian steel workers," Occupational and Environmental Medicine, vol. 54, no. 8, pp. 599-604, 1997.

[18] T. K. Saha, A. Dasgupta, A. Butt, and O. Chattopadhyay, "Health status of workers engaged in the small-scale garment industry: how healthy are they," Indian Journal of Community Medicine, vol. 35, no. 1, pp. 179-182, 2010.

[19] K. Ulm, B. Waschulzik, H. Ehnes et al., "Silica dust and lung cancer in the German stone, quarrying, and ceramics industries: results of a case-control study," Thorax, vol. 54, no. 4, pp. 347351, 1999.

[20] P. Sebastien, J. C. McDonald, A. D. McDonald, B. Case, and R. Harley, "Respiratory cancer in chrysotile textile and mining industries: exposure inferences from lung analysis," British Journal of Industrial Medicine, vol. 46, no. 3, pp. 180-187, 1989.
[21] S. Kerketta, R. Gartia, and S. Bagh, "Determination of the test frequency causing significant hearing loss of the mine workers of an open cast chromite mine," International Journal of Modern Engineering Research, vol. 2, no. 4, pp. 2832-2838, 2012.

[22] G. K. Medhi, N. C. Hazarika, B. Shah, and J. Mahanta, "Study of health problems and nutritional status of tea garden population of Assam," Indian Journal of Medical Sciences, vol. 60, no. 12, pp. 496-505, 2006.

[23] D. P. Punde, "Management of snake-bite in rural Maharashtra: a 10-year experience," National Medical Journal of India, vol. 18, no. 2, pp. 71-75, 2005.

[24] M. Moses, "Pesticide-related health problems and farmworkers," AAOHN Journal, vol. 37, no. 3, pp. 115-130, 1989.

[25] J. Shigemi, Y. Mino, T. Tsuda, A. Babazono, and H. Aoyama, "The relationship between job stress and mental health at work," Industrial Health, vol. 35, no. 1, pp. 29-35, 1997.

[26] I. Nazarova, "Self-rated health and occupational conditions in Russia," Social Science and Medicine, vol. 51, no. 9, pp. 1375-1385, 2000.

[27] M. A. Colchero, B. Caballero, and D. Bishai, "The effect of income and occupation on body mass index among women in the Cebu Longitudinal Health and Nutrition Surveys (19832002)," Social Science and Medicine, vol. 66, no. 9, pp. 1967-1978, 2008.

[28] P. Bigoniya, A. Shukla, and C. S. Singh, "A survey on the occupational health status of gardeners in Bhopal, India," Indian Journal of Community Medicine, vol. 35, no. 4, pp. 487-490, 2010.

[29] K. Nakamura, S. Shimai, S. Kikuchi et al., "Increases in body mass index and waist circumference as outcomes of working overtime," Occupational Medicine, vol. 48, no. 3, pp. 169-173, 1998.

[30] S. Koley, N. Kaur, and J. S. Sandhu, "A study on hand grip strength in female labourers of Jalandhar, Punjab, India," Journal of Life Sciences, vol. 1, no. 1, pp. 57-62, 2009.

[31] A. Bandyopadhyay, "Body composition and hand grip strength in male brick-field workers," Malaysian Journal of Medical Sciences, vol. 15, no. 1, pp. 31-36, 2008.

[32] S. Chatterjee, S. K. Mitra, and A. Samanta, "Aerobic capacity of the brick-field workers in Eastern India," Industrial Health, vol. 32, no. 2, pp. 79-84, 1994.

[33] M. R. Choudhury, The Tea Industry in India: A Diagnostic Analysis of Its Geoeconomic Studies, Oxford Book and Stationary Company, Calcutta, India, 1978.

[34] J. S. Weiner and J. A. Lourie, Eds., Practical Human Biology, Academic Press, London, UK, 1981.

[35] J. V. Dacie, Practical Haematology, Churchill, London, UK, 1958.

[36] J. E. L. Carter and B. H. Heath, Somatotyping-Developments and Applications, Cambridge University Press, Cambridge, UK, 1990.

[37] WHO Expert Consultation, "Appropriate body-mass index for Asian populations and its implications for policy and intervention strategies," The Lancet, vol. 363, no. 9403, pp. 157-163, 2004.

[38] World Health Organization, Haemoglobin Concentrations for the Diagnosis of Anaemia and Assessment of Severity. Vitamin and Mineral Nutrition Information System, (WHO/NMH/NHD/MNM/11.1), World Health Organization, Geneva, Switzerland, 2011.

[39] A. V. Chobanian, G. L. Bakris, H. R. Black et al., "The seventh report of the Joint National Committee on Prevention, Detection, Evaluation, and Treatment of High Blood Pressure: the 
JNC 7 report," Journal of the American Medical Association, vol. 289, no. 19, pp. 2560-2572, 2003.

[40] S. Chakrabarty and P. Bharati, "Adult body dimension and determinants of chronic energy deficiency among the Shabar tribe living in urban, rural and forest habitats in Orissa, India," Annals of Human Biology, vol. 37, no. 2, pp. 149-167, 2010.

[41] S. Ghosh and S. L. Malik, "Sex differences in body size and shape among Santhals of West Bengal," Anthropologist, vol. 9, no. 2, pp. 143-149, 2007.

[42] M. K. Bhasin and J. Sweta, "Biology of the tribal groups of Rajasthan, India: physical growth and anthropometric somatotypes," Anthropologist, vol. 9, no. 3, pp. 177-187, 2007.

[43] S. Ghosh and S. L. Malik, "Variations of body physique in santhals: an Indian tribe," Collegium Antropologicum, vol. 34, no. 2, pp. 467-472, 2010.

[44] S. K. Roy, "The concept and method of anthropometric somatotype, with an example from the Oraon tea garden laoburers of Jalpaiguri District, West Bengal," Journal of Indian Anthropological Society, vol. 25, pp. 129-140, 1990.

[45] P. C. Mittal and S. Srivastava, "Diet, nutritional status and food related traditions of Oraon tribes of New Mal (West Bengal), India," Rural and Remote Health, vol. 6, no. 1, p. 385, 2006.

[46] R. Chakraborty, K. Bose, and S. Koziel, "Use of mid-upper arm circumference in determining undernutrition and illness in rural adult Oraon men of Gumla District, Jharkhand, India," Rural and remote health, vol. 11, no. 3, p. 1754, 2011.

[47] S. D. Banik, "Nutritional status of adult men from the Oraon tribe in Ranchi District of Jharkhand, India," Malaysian Journal of Nutrition, vol. 14, no. 1, pp. 91-99, 2008.

[48] D. Biswas, N. C. Hazarika, D. Hazarika, P. Doloi, and J. Mahanta, "Study on nutritional status of tea garden workers of Assam with special emphasis to body mass index (BMI) and central obesity," Journal of Human Ecology, vol. 13, no. 4, pp. 299-302, 2002.

[49] L. London, V. Nell, M.-L. Thompson, and J. E. Myers, "Health status among farm workers in the Western Cape-collateral evidence from a study of occupational hazard," South African Medical Journal, vol. 88, no. 9, pp. 1096-1101, 1998.

[50] T. G. Mahanta, F. U. Ahmed, B. N. Mahanta, and A. Barua, "Prevalence of hypertension and its risk factors in a tea garden community of Dibrugarh District, Assam," Indian Journal of Public Health, vol. 52, no. 1, pp. 45-47, 2008.

[51] J. S. House, J. Wells, and A. J. McMichael, "Occupational stress and health among factory workers," Journal of Health and Social Behavior, vol. 20, no. 2, pp. 139-160, 1979.

[52] R. A. Karasek, D. Baker, F. Marxer, A. Ahlbom, and T. Theorell, "Job decision latitude, job demands, and cardiovascular disease: a prospective study of Swedish men," American Journal of Public Health, vol. 71, no. 7, pp. 694-705, 1981. 

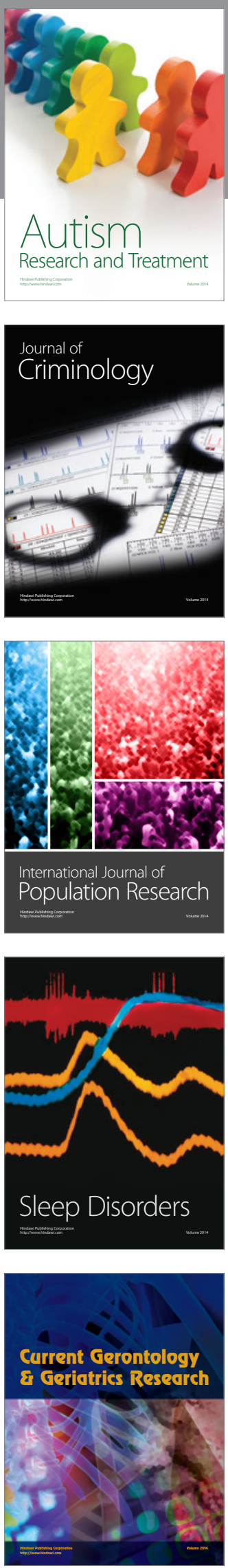
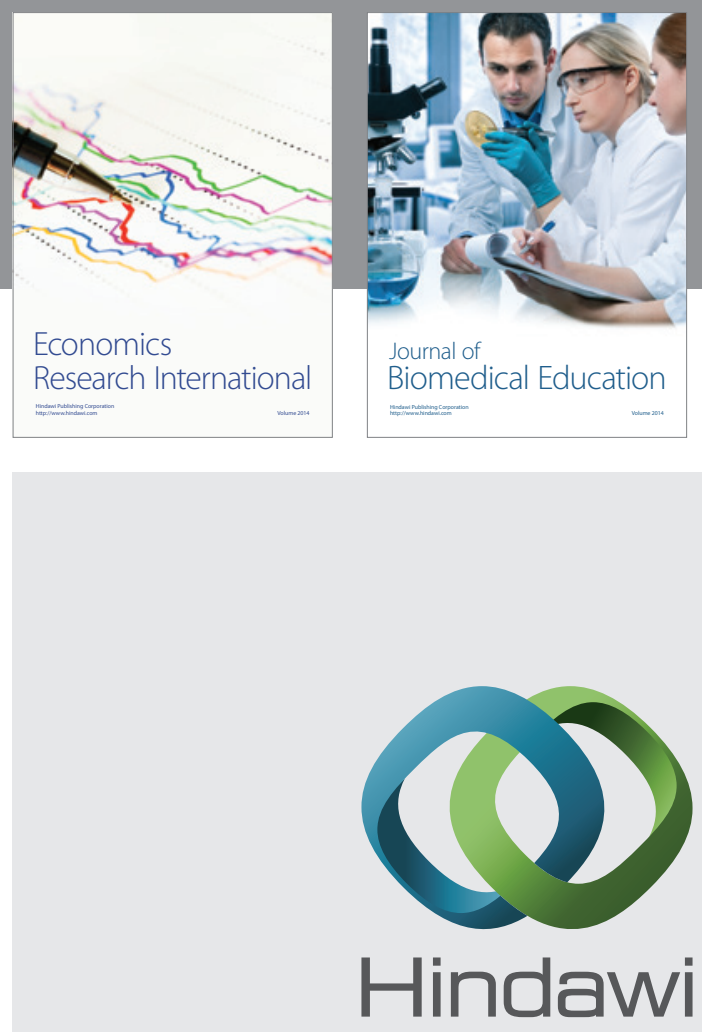

Submit your manuscripts at

http://www.hindawi.com
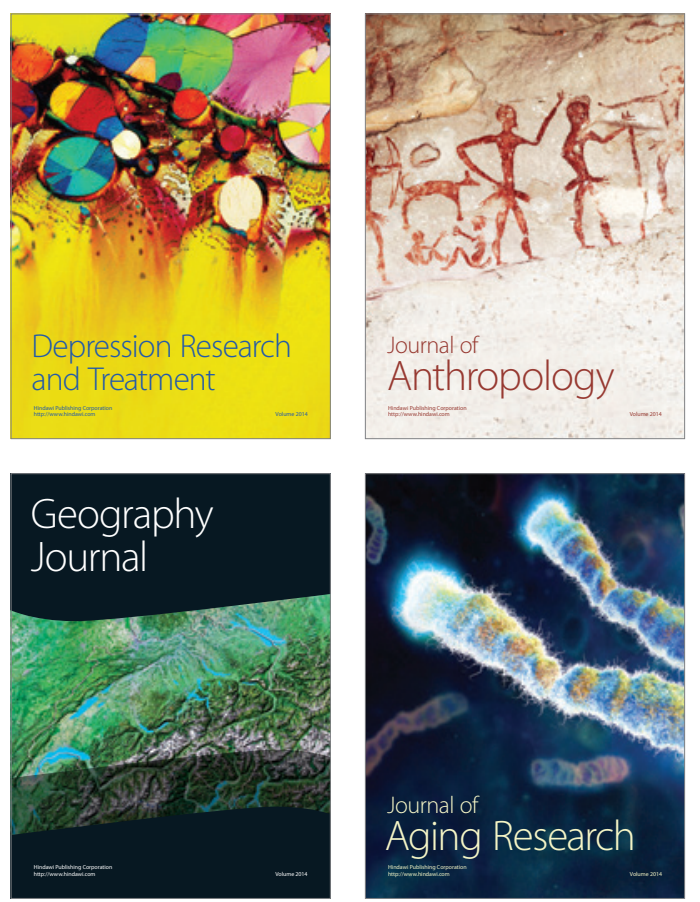
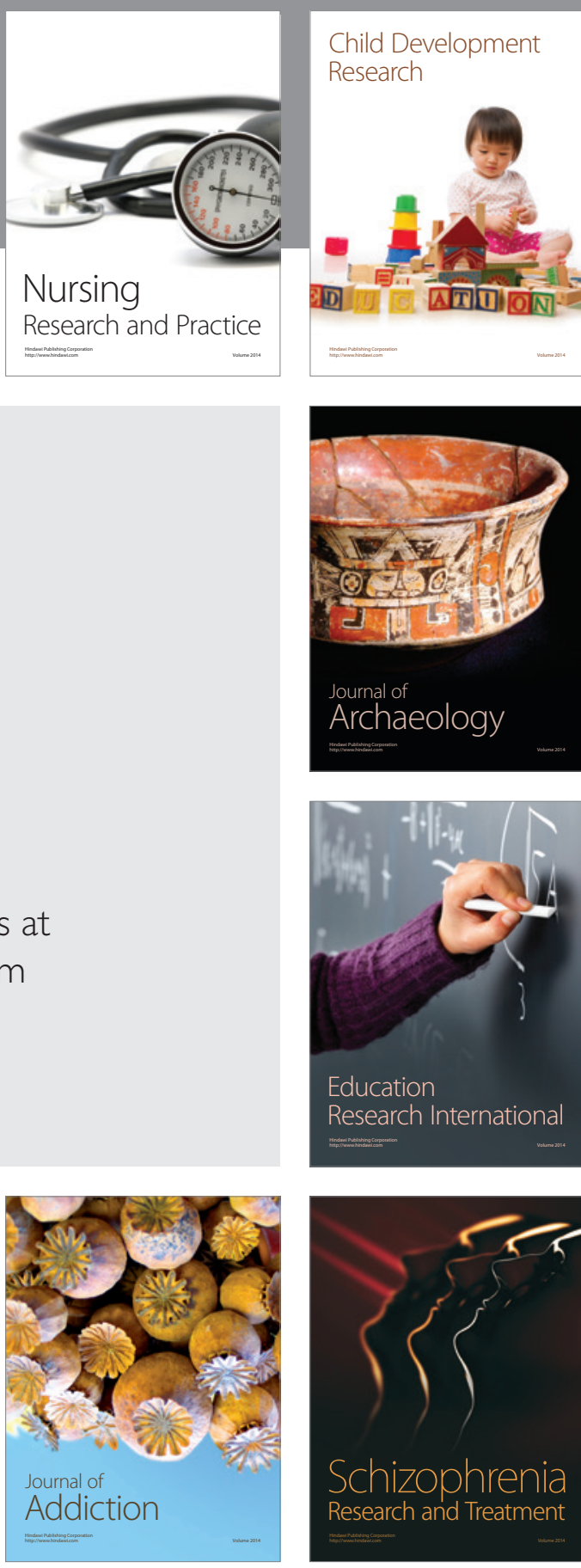

(D)
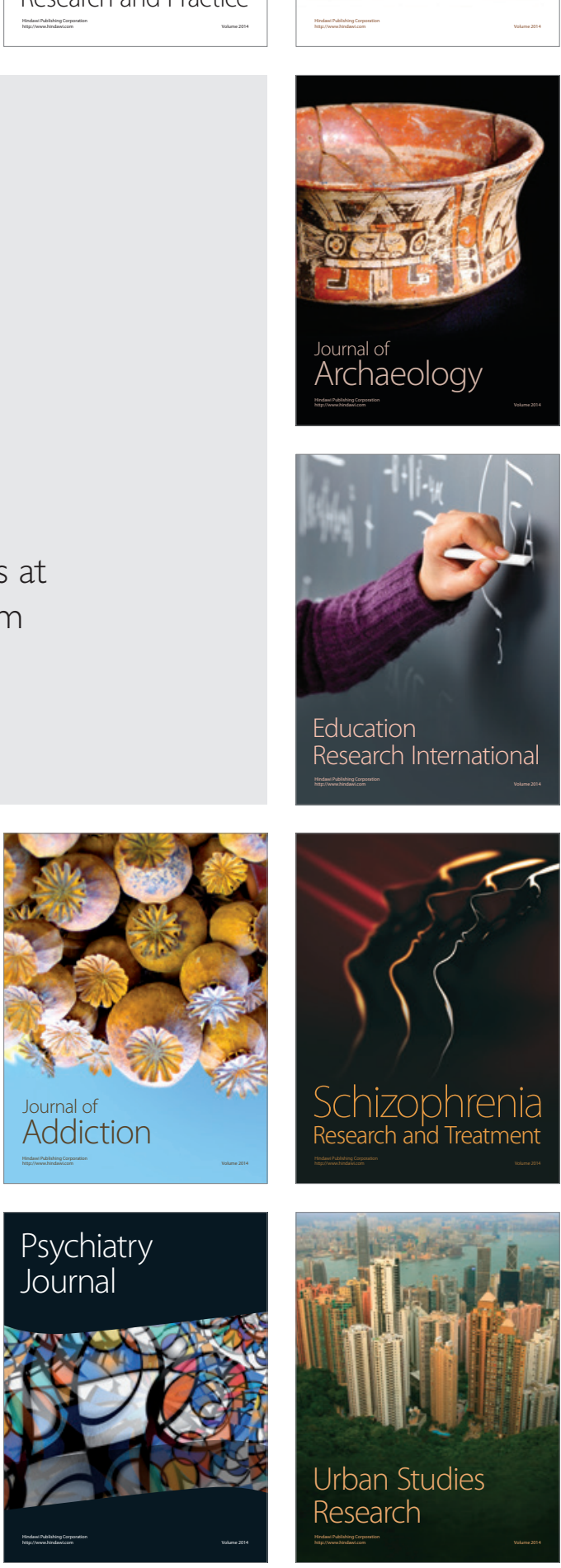